\title{
Companion Animals: A Potential Threat in Emergence and Transmission of Parasitic Zoonoses
}

\section{Magudeswara Moorthi Senthil Murugan ${ }^{*}$, Kandasamy Arunvikram², Selvaraj Pavulraj ${ }^{3}$, Arockiasamy Arun Prince Milton ${ }^{4}$, Dharmendra Kumar Sinha ${ }^{1}$, Bhoj Raj Singh ${ }^{1}$}

\begin{abstract}
${ }^{1}$ Division of Epidemiology; ${ }^{2}$ Division of Pharmacology and Toxicology; ${ }^{4}$ Division of Veterinary Public Health, ICAR-Indian Veterinary Research Institute, Izatnagar, Bareilly (UP)-243122, India; ${ }^{3}$ Equine Pathology Laboratory, ICAR-National Research Centre on Equines (ICAR-NRCE), Hisar, Haryana-125001, India.
\end{abstract}

\begin{abstract}
Recent emergence of zoonotic-parasitic diseases in humans are due to evolution of microbes or parasites with alterations of host ranges, vector system, infectivity, virulence and/or re-occurrence of an unreported infection. Although, zoonotic parasitic diseases of companion animal origin are very familiar and deliberately studied in American and European countries, they are under prioritized areas of human health concern in developing countries like India. Circumstances prevailing in developing countries are favourable for easy and diffuse transmission and surfacing of zoonotic parasitic infections viz. toxoplasmosis, giardiasis, toxacariasis, echinoccosis, leishmaniasis, etc. However, with the implementations of personal hygiene and sanitary measures, appearance and spread of such zoonotic parasitic infections from companion animals can be prevented. Pet owners must be educated in a right way about the potential zoonotic risks, mode of transmission of these infections from their pets. It has been concluded that veterinarians need to play an immense role in educating and creating awareness on transmission and prevention of companion animal zoonoses in humans. This review discusses about the common parasitic zoonoses of companion animals. The primary focus of this review is mostly about canine and feline parasitic zoonoses that were the major threat in the developing nations.
\end{abstract}

Keywords | Companion animals, Zoonoses, Emergence, Parasitic infections, Transmission

Editor | Kuldeep Dhama, Indian Veterinary Research Institute, Uttar Pradesh, India.

Received | April 14, 2015; Revised | April 17, 2015; Accepted | September 18, 2015; Published | October 21, 2015

*Correspondence | Magudeswara Moorthi Senthil Murugan, ICAR-Indian Veterinary Research Institute, Bareilly, India; Email: drsenvets@gmail.com

Citation | Murugan MMS, Arunvikram K, Pavulraj S, Milton AAP, Sinha DK, Singh BR (2015). Companion animals: A potential threat in emergence and transmission of parasitic zoonoses. Adv. Anim. Vet. Sci. 3(11): 594-604.

DOI | http://dx.doi.org/10.14737/journal.aavs/2015/3.11.594.604

ISSN (Online) | 2307-8316; ISSN (Print) | 2309-3331

Copyright (C) 2015 Murugan et al. This is an open access article distributed under the Creative Commons Attribution License, which permits unrestricted use, distribution, and reproduction in any medium, provided the original work is properly cited.

\section{INTRODUCTION}

$\mathrm{P}$ et animals play a significant role in societies all over the world. They are vital companions in numerous households, contributing to the social, physical, mental and emotional development of kids, and owners in particularly aged people (Zasloff, 1994; Jennings, 1997). They are considered as one of the family member in the home. When we know the benefits of the association between human and animals, we should also concern about the spread of diseases from them (Paul et al., 2010). Furthermore, pet owners stopover their physician less often, use less medication and have lesser blood pressure and cholesterol levels with cool mind than those do not have pets in their home (Headey, 1999). It has been documented that health risks viz., bites of animals and skin-allergy are the common health associ- ated risks with pets (Milton et al., 2015; Saminathan et al., 2015). But, various ranges of infections and infestations, including bacterial, viral, fungal and parasitic diseases, are in a way of being transmitted to humans from pets (Plant et al., 1996; Geffray, 1999). Zoonoses and diseases due to parasites are often underappreciated. It leads to diseases and cause may be managed inappropriately or gone undiagnosed (Paul et al., 2010). The possible health hazard to man due to GI parasites harbored by pet animals leaves a major crisis in different parts of the earth (Schantz, 1994). Zoonotic parasitic diseases spread to humans by ingestion of infectious intermediate stages viz. oocysts, cysts, spores, ova, larva or larval stages or by consumption of raw or undercooked meat with infective stages in tissues (Milton et al., 2015). Humans may act as final, intermediate, paratenic or accidental hosts in the life cycle of the parasite. 
The common and rare parasitic zoonoses associated with companion animals and the agents causing the disease in humans are discussed in Table 1 and 2, respectively, and exotic companion animal parasitic zoonoses are discussed in Table 3.

\section{PARASITIC ZOONOSES IN INDIA}

It has been predicted that more than 19.2 million mongrel dogs are there in India in spite of several control measures (WHO, 1996). Countries like India, unrestrained stray and semi-domesticated canine lives in close association with growing densities of humans in urban cities. Humans frequently have a close association with semi-domesticated canines in rural surroundings (Dutta, 2002). These socio-economically underprivileged communities with the low levels of sanitation and hygiene, over-crowding ever growing population, deficient of veterinary attention and potential zoonotic awareness, aggravates the chances for zoonotic disease transmissions (Schantz, 1991). The surveillance and control of zoonotic diseases of canines in India is unprioritized in disparity to other human health harms with huge of morbidity, mortality and case fatality, like HIV/AIDS, malaria, tuberculosis and other childhood diseases (WHO, 2003). Common parasitic zoonoses viz. hydatid disease from canines (Bhandarkar and Talvalkar, 1973; Bhojraj and Shetty, 1999) and toxocariasis from felines (Mirdha and Khokar, 2002; Malla et al.,2002) are sporadic in nature. In spite of demonstrating strong endemicity of several parasitic zoonotic diseases (Table 1 and 2) from

Table 1: Common parasitic zoonoses from companion animals

\begin{tabular}{|c|c|c|c|c|c|}
\hline $\begin{array}{l}\text { Disease in com- } \\
\text { panion animals }\end{array}$ & $\begin{array}{l}\text { Parasitic zo- } \\
\text { onotic agent }\end{array}$ & Disease in humans & Diagnostic techniques & Prevalence & References \\
\hline \multirow[t]{2}{*}{ Echinococosis } & $\begin{array}{l}\text { Eccbinococcous } \\
\text { granuloses }\end{array}$ & $\begin{array}{l}\text { Cystic echinococ- } \\
\text { cosis }\end{array}$ & Histopathology & $\begin{array}{l}6-8 \% \text { in small } \\
\text { ruminants }\end{array}$ & $\begin{array}{l}\text { Macpherson } \\
\text { (2003); Romig et } \\
\text { al. (2015); Khan } \\
\text { et al. (2015) }\end{array}$ \\
\hline & $\begin{array}{l}\text { Echinococcus } \\
\text { multilocularis }\end{array}$ & $\begin{array}{l}\text { Alveolar echinococ- } \\
\text { cosis }\end{array}$ & $\begin{array}{l}\text { Microscopy, ELISA for } \\
\text { coproantigen detection and } \\
\text { copro-DNA detection by PCR }\end{array}$ & $70 \%$ & $\begin{array}{l}\text { Conraths } \\
\text { and Deplazes } \\
\text { (2015) }\end{array}$ \\
\hline Toxoplasmosis & $\begin{array}{l}\text { Toxoplasma } \\
\text { gondii }\end{array}$ & $\begin{array}{l}\text { Congenital and Oc- } \\
\text { ular Toxoplasmosis }\end{array}$ & IgM and IgG ELISA & $\begin{array}{l}30-50 \% \text { in or- } \\
\text { ganic free range } \\
\text { farming }\end{array}$ & $\begin{array}{l}\text { Dubey (2010); } \\
\text { Tenter et al. } \\
(2000)\end{array}$ \\
\hline Toxacariasis & $\begin{array}{l}\text { Toxacara canis, } \\
\text { Toxacara cati }\end{array}$ & $\begin{array}{l}\text { Visceral and Ocular } \\
\text { Larval Migrans }\end{array}$ & $\begin{array}{l}\text { ELISA with Toxocara spp. } \\
\text { excretory-secretory (TES) } \\
\text { antigen or Western blot, larva } \\
\text { can be detected by ultrasound, } \\
\text { computed tomography (CT) } \\
\text { and magnetic resonance imag- } \\
\text { ing (MRI) }\end{array}$ & $\begin{array}{l}2 \% \text { to } 44 \% \text { in } \\
\text { human, } 3.5 \% \text { to } \\
34 \% \text { in dogs, } 8 \% \\
\text { to } 76 \% \text { in cats }\end{array}$ & $\begin{array}{l}\text { Smith et al. } \\
(2009) ; \\
\text { Lee et al. (2010) }\end{array}$ \\
\hline Ancylostomiasis & $\begin{array}{l}\text { Ancylostoma } \\
\text { caninum }\end{array}$ & $\begin{array}{l}\text { Cutaneous Larval } \\
\text { Migrans }\end{array}$ & $\begin{array}{l}\text { Microscopy for faecal smear, } \\
\text { PCR, PCR-RFLP, DNA } \\
\text { sequencing }\end{array}$ & $14 \%$ in dogs & $\begin{array}{l}\text { Traub et al. } \\
\text { (2008); } \\
\text { Schantz (1999) }\end{array}$ \\
\hline Giardiasis & $\begin{array}{l}\text { Giardia duode- } \\
\text { nalis }\end{array}$ & GI disturbances & $\begin{array}{l}\text { Microscopy for faecal smear } \\
\text { (centrifugal sedimentation and } \\
\text { centrifugal flotation) }\end{array}$ & $70.5 \%$ in human & $\begin{array}{l}\text { Almeida et al. } \\
\text { (2015) }\end{array}$ \\
\hline $\begin{array}{l}\text { Cryptosporid- } \\
\text { iosis }\end{array}$ & $\begin{array}{l}\text { Cryptosporidum } \\
\text { parvum }\end{array}$ & Rare infection & $\begin{array}{l}\text { Microscopy for faecal smear, } \\
\text { DNA Sequencing, immuno- } \\
\text { fluorescence antibody test, } \\
\text { PCR }\end{array}$ & & $\begin{array}{l}\text { Forester et al. } \\
\text { (2010) }\end{array}$ \\
\hline Leishmaniasis & $\begin{array}{l}\text { Leishmania } \\
\text { infantum }\end{array}$ & $\begin{array}{l}\text { Cutaneous and } \\
\text { Visceral Leishhma- } \\
\text { niasis }\end{array}$ & $\begin{array}{l}\text { Microscopy for faecal smear, } \\
\text { indirect fluorescence antibody } \\
\text { (IFA), enzyme-linked immu- } \\
\text { nosorbent assay (ELISA) or } \\
\text { western blot }\end{array}$ & $42 \%$ in dogs & $\begin{array}{l}\text { Molina et al. } \\
\text { (1994); } \\
\text { Sharma et al. } \\
\text { (2003) }\end{array}$ \\
\hline Dipylliodiosis & $\begin{array}{l}\text { Dipyllidium } \\
\text { caninum }\end{array}$ & $\begin{array}{l}\text { Children are af- } \\
\text { fected }\end{array}$ & $\begin{array}{l}\text { Microscopy for faecal smear, } \\
\text { enzyme-linked immuno- } \\
\text { sorbent assay (ELISA) or } \\
\text { western blot }\end{array}$ & $16.63 \%$ in dogs & $\begin{array}{l}\text { Zanzani et al. } \\
\text { (2014) }\end{array}$ \\
\hline
\end{tabular}


Table 2: Rare parasitic zoonoses from companion animals

\begin{tabular}{|c|c|c|c|c|c|c|}
\hline Disease & Country & Etiology & $\begin{array}{l}\text { Vector / } \\
\text { source }\end{array}$ & Diagnostic techniques & $\begin{array}{l}\text { Preva- } \\
\text { lence }\end{array}$ & References \\
\hline Babesiosis & USA & $\begin{array}{l}\text { Babesia canis, } \\
\text { B.conrade }\end{array}$ & Ixodes ricinus & $\begin{array}{l}\text { Giemsa or Wright's stained blood } \\
\text { smears, UV illumination after staining } \\
\text { with acridine orange, serological tests, } \\
\text { PCR }\end{array}$ & & $\begin{array}{l}\text { Johnson et al. } \\
\text { (2009) }\end{array}$ \\
\hline $\begin{array}{l}\text { Chagas Disease } \\
\text { (American trypa- } \\
\text { nosomiasis) }\end{array}$ & USA & $\begin{array}{l}\text { Trypanosoma } \\
\text { cruzi }\end{array}$ & $\begin{array}{l}\text { Triatomine } \\
\text { bugs }\end{array}$ & $\begin{array}{l}\text { Blood smears, serological tests, PCR, } \\
\text { ELISA, IFA, immunochromatic tests }\end{array}$ & $\begin{array}{l}42 \% \text { in } \\
\operatorname{dogs}\end{array}$ & $\begin{array}{l}\text { Kjos et al. } \\
(2008)\end{array}$ \\
\hline $\begin{array}{l}\text { Canine Heart } \\
\text { worm }\end{array}$ & USA & $\begin{array}{l}\text { Dirofilaria } \\
\text { immitis }\end{array}$ & $\begin{array}{l}\text { Ctenocephal- } \\
\text { ides canis }\end{array}$ & $\begin{array}{l}\text { Wet blood smear, Knott's method, } \\
\text { PCR and DNA sequencing techniques }\end{array}$ & $\begin{array}{l}4-13 \% \\
\text { in dogs }\end{array}$ & $\begin{array}{l}\text { Simon et al. } \\
(2012)\end{array}$ \\
\hline $\begin{array}{l}\text { Paragonimiasis } \\
\text { (Lung Fluke) }\end{array}$ & China & $\begin{array}{l}\text { Paragonimus } \\
\text { westermanii }\end{array}$ & $\begin{array}{l}\text { Crabs, Cray } \\
\text { fish }\end{array}$ & $\begin{array}{l}\text { Microscopy of sputum smear, biopsy, } \\
\text { pleural fluid, faecal egg. Intradermal } \\
\text { (ID) test, complement fixation test } \\
\text { (CFT), immunodiffusion, indirect } \\
\text { haemagglutination test (IHA), } \\
\text { enzyme-linked immunosorbent assay } \\
\text { (ELISA), dot-ELISA, and Western } \\
\text { blot }\end{array}$ & $\begin{array}{l}8.3 \% \text { in } \\
\text { cats }\end{array}$ & $\begin{array}{l}\text { Xu et al. } \\
\text { (2005); } \\
\text { Liu et al. } \\
\text { (2008) }\end{array}$ \\
\hline Clonorchiasis & China & $\begin{array}{l}\text { Clonorchis } \\
\text { sinensis }\end{array}$ & Fish, shrimp & $\begin{array}{l}\text { Microscopy for faecal smear, ultra- } \\
\text { sound examination, magnetic reso- } \\
\text { nance imaging (MRI), tissue harmonic } \\
\text { imaging (THI), immunological ap- } \\
\text { proaches, PCR and DNA sequencing }\end{array}$ & & $\begin{array}{l}\text { Qian et al. } \\
\text { (2015) }\end{array}$ \\
\hline Trichnosis & China & $\begin{array}{l}\text { Trichinella } \\
\text { spiralis }\end{array}$ & Dog meat & $\begin{array}{l}\text { Microscopy for faecal smear, meat } \\
\text { inspection, eosinophilia, and elevat- } \\
\text { ed creatinine kinase, biopsy, ELISA, } \\
\text { DNA sequencing, PCR }\end{array}$ & $\begin{array}{l}7-40 \% \\
\text { in dogs }\end{array}$ & $\begin{array}{l}\text { Zhou et al. } \\
\text { (2008); Fran- } \\
\text { co Sandoval } \\
\text { et al. (2012) }\end{array}$ \\
\hline
\end{tabular}

Table 3: Exotic companion animal zoonoses

\begin{tabular}{|llll} 
Species & Zoonotic parasitic disease & Diagnostic techniques & Reference \\
Rabbits & $\begin{array}{l}\text { Cheyletiella parasitivorax } \\
\text { (Mite) }\end{array}$ & $\begin{array}{l}\text { Skin scrapping (flea comb and potassium hydroxide } \\
\text { technique), skin biopsy }\end{array}$ & Frank et al. (2013) \\
Rats & $\begin{array}{l}\text { Hymenolepis diminuta (ces- } \\
\text { tode) }\end{array}$ & $\begin{array}{l}\text { Microscopy of faecal egg smear, larval staining with } \\
\text { Semichon's acetocarmin and counterstained with } \\
\text { fast green }\end{array}$ & d'Ovidio et al. (2015) \\
Rodents & Trixacarus caviae (Acariasis) & Skin scrapping (Faure's method) & Singh et al. (2013) \\
\hline Snakes & $\begin{array}{l}\text { Pentostomiasis (Armillifer } \\
\text { armillatus) }\end{array}$ & $\begin{array}{l}\text { Microscopy of faecal egg smear, DNA Sequencing } \\
\text { and PCR, histopathology }\end{array}$ & $\begin{array}{l}\text { Hendrix and Blagburn (1988); } \\
\text { Tappe et al. (2013) }\end{array}$ \\
Fish & $\begin{array}{l}\text { Clonorchiasis, Diphyllo- } \\
\text { bothriosis, Gnathostomiasis }\end{array}$ & $\begin{array}{l}\text { Microscopy of faecal egg smear, DNA Sequencing } \\
\text { and PCR, histopathology }\end{array}$ & $\begin{array}{l}\text { Chai et al. (2005); Jongthawin et } \\
\text { al. (2015); Rivero et al. (2015) }\end{array}$
\end{tabular}

dogs, felines, rabbits, fishes, rodents, snakes (Table 3), etc.understanding, knowledge on pervasiveness of the risk factors allied with zoonotic parasites are fundamentally deficient.

\section{RISK POTENTIAL OF PARASITIC ZOONOTIC DISEASES}

Potential zoonotic parasitic diseases spread by close interactions of pets with children, pregnant womens and immunocompromised individuals (Juckett, 1997; Mani and Maguire, 2009). Efficient control of parasitic zoonoses depends on complete understanding of life cycle of parasites, especially in infections where humans participate in perpetuating the transmission cycles (Thompson, 1999). For example, the threat of getting cerebral toxoplasmosis is not augmented by having a pet cat, in many case, infection occurred due to reactivation of latent infections due to consumption of undercooked meats (Frenkel, 1990). Risk of getting zoonotic infections in humans increased to several magnitude by occupational exposure particularly in veterinarians, pet owners, farmers, animal handlers, animal researchers, butchers, etc. (Kahn, 2006; Baker, 2009; Now- 
otny, 2000).

\section{MODES OFTRANSMISSION}

Common modes of zoonotic transmission occurs through direct contact on skin and mucous membranes by animal bites, scratches, or contact with infected animal faeces, urine, saliva, other body fluids and fomites. Further, ingestion of food and water contaminated with faeces, inhalation of aerosolized infectious droplets, vectors and other invertebrates also a common mode of transmissions (Mani and Maguire, 2009).

\section{Mechanical Transmitters of Human Parasites}

The role of the dog as a mechanical reservoir for human parasites were observed in tea-growing personnel in Assam, where parasitic stages which supposed to be host-specific for humans such as Ascaris spp. Trichuris trichiura, Hymenolepis diminuta and Isospora belli were detected in canine faeces (Traub et al., 2002). About 30\% of Ascaris eggs were detected in canine faeces produced motile larvae when subjected 2 to 6 weeks after incubation at room temperature. Recently, Polymerase chain reactions based Restriction fragment length polymorphism method developed for identification of different species of Ascaris ova directly from canine faeces, reveled abundance of Ascaris lumbricoides in sampled canines which signifies the role of canines as a possible involuntary transmitter and disseminator of Ascaris to humans; it increases the contact of infective stages of parasitic eggs to human population (Traub et al., 2002). Mechanical transmission of zoonotic disease by dogs is the least ignored aspect in socio-economically underprivileged parts of Asia, South America, Australia and Africa (Sterneberg-van der Maaten et al., 2015).

\section{HUMAN BEHAVIOUR AND EMERGENCE OF PARASITIC ZOONOSES}

Omnipresent distribution of canines all over the world in forms of pet dogs, stray, mongrel and feral dogs, has a synanthropic relationship with human being, makes a significant role in transmission of zoonotic disease (Macpherson, 2005). Close human association with canine and felines due to companionship resulted in unwanted sharing of more than 60 parasitic species, viz. Echinococcus spp., Diphyllobothrum, Ancylostoma, Toxocara spp., Giardia spp., Cryptosporidium spp. and Toxoplasma spp. (Sterneberg-van der Maaten et al., 2015).

Behavior of human beings towards pet dogs has significant role in the maintenance of parasitic infections due to cestode, mainly Echinococcus granulosus, which causes Cystic Echinococcosis (CE) and Echinococcus multilocularis which causes Alveolar Echinococcosis (AE) (Macpherson et al., 2003). Canine are considered as definitive hosts for E. multilocularis (Thompson et al., 2003). In countries like India, where uncontrolled stray dogs intentionally fed offal of other animals results in higher incidence of E. granulosus (Macpherson et al., 1985). Developing countries do not have stringent dog population control programs and people also have dogs as pets (Akakpo, 1985; Conraths and Deplazes, 2015), but still, rearing of dogs as pet is of very small proportion (Dar and Alkarmi, 1997; Romiq et al., 2015).

\section{CYSTIC AND ALVEOLAR ECHINOCOCCOSIS}

Hydatid cysts - the larval stages of E. granulosus and is causal organism of cystic echinococcosis in humans (Eckert et al., 2000a). E. granulosus is a cestode, in its life cycle it has canine and other species of canids as final definitive. In some cases domestic and other wild ungulates may act as an intermediate hosts for larval stages of parasite (Thompson, 1995). Metacestode stage of E. multilocularis causes alveolar echinococcosis in humans (Khan et al., 2015). These parasites perpetuate in silvatic life cycle with wild foxes as final hosts and rodent act as intermediate hosts. The metacestode stage also called as echinococcal cyst characterized by spherical, fluid-filled, cyst, comprise of an inner germinal layer of cells supported by acellular, acidophilic-staining, laminated membrane of inconsistent thickness (Moro et al., 2008, Romig et al., 2015). Development of metacestode cysts observed in almost all anatomic sites of the body after ingestion of E. granulosus ova, but, cyst commonly observed in liver and lungs (Pawlowski, 1997; Eckert et al., 2000c). Distributions of E. granulosus have been reported in all over the world, irrespective of geographical limitations (Eckert, 2000b).

\section{Emergence and Transmission of Cystic}

\section{Echinococcosis}

Feeding of canines with sheep offal causes transmission of sheep strains to dogs and then to humans (Moro et al., 2008). Dogs infected with Echinococcus tapeworms excrete the ova in faeces and humans get infection by fecal-oral route of transmission. Further, parasitic ova may attach to hairs near the anal region of infected dogs, and also around muzzle and paws. Infection may also spread by contaminated water, food due to mechanical transmission of eggs in to it (Moro et al., 2009). Maximum occurrence of cystic echinococcosis in animals and humans are observed in temperate countries like, southern South America, Mediterranean littoral, central Asia, China, southern and central parts of the former Soviet Union, Australia and Africa (Yang et al., 2006; Moro and Schantz, 2006; Conraths and Deplazes, 2015). 
Emergence And Transmission of AlveOlar ECHINOCCOSIS

Infection of metacestode (larval) stage of $E$. multilocularis causes AE in humans (Conraths and Deplazes, 2015). Foxes and rodents act as definitive host and intermediate host for E. multilocularis respectively (McManus et al., 2003). Domestic canines and feline may get infection by eating infected wild rodents from wild. Encroachments of foxes from wild to urban and suburban areas increase the probability of getting infection to dogs (Eckert et al., 2004). Cats are less susceptible to infection than canines (Kapel et al., 2006). Close association of pet dogs with humans increase the risk of infection with $\mathrm{AE}$. It has been well documented that dogs are considered as appropriate definitive hosts for E. multilocularis (Thompson et al., 2003). Parameters associated with emergence of $E$. multilocularis infection includes increased fox populations and prevalence of parasite, invasion of cities and villages by foxes and transmission of diseases in humans by dogs and cats (Eckert, 2000a).

\section{Transmission OF TOXACARIASIS}

The genus Toxocara contains two species, Toxocara canis and Toxocara cati which are widespread parasites of canines and felines, respectively. Transplancental transmission to puppies and trans-mammary transmission in kittens are the main route of infections. Canines and feline acquiring patent infection of Toxocara spp. at any age by ingestion of ova or paratenic hosts (Garden lizard). Clinical signs of infection include abdominal discomfort, diarrhea, emesis, stunted growth and intestinal obstruction in rare cases. Human infection occurs due to accidental ingestion of embryonated eggs from contaminated soil, water, food, fomites or by direct contact with infected dogs and cats (Smith et al., 2009) which may results in ocular larva migrans (OLMs), visceral larva migrans (VLMs), neurotoxocarosis, eosinophilic meningoencephalitis (EME) and covert toxocariasis (CT) (Finsterer and Auer, 2007; Rubinsky-Elefant et al., 2010). Cases of human larval toxocariasis are well documented with different signs of infection as described. Some manifestations may lead to enduring ocular or neurological damage, which emphasizing role for physician and veterinarians in educating the public community on modes of transmission of infection, populations at risk, and prevention and control measures (Lee et al., 2010).

\section{DOG'S HAIR - POTENTIAL TRANSMITTER OFTOXACARA EGGS}

Transmission mainly occurs by direct contact with dogs or by contaminated soils (Roddie et al., 2008). Wolfe and Wright (2003) proposed a hypothesis that humans may get infection by ingestion of embryonated eggs directly from hair coat of a dog (more than $20 \mathrm{Egg}$ per gram of hair). It has been estimated that density of eggs in hairs is much higher than eggs found in soil (Jacobs et al., 1977; Holland et al., 1991; O'Lorcain, 1994a). Roddie et al. (2008) reported that more than $67 \%$ of the canines were positive for Toxocara eggs in their hair coat, out of $82.4 \%$ of all the eggs recovered were viable and embryonated. Furthermore, $94 \%$ of embryonated eggs were seen on puppies and adult dog harbors few as $0.6 \%$ of embryonated eggs (Roddie et al., 2008).

The shorter hairs on puppies allow heat transfer to parasitic eggs and may be favourable environment for development of larvae in eggs. Numbers of worms in puppies also correlated with maximum intensities of eggs on the hair. All this suggests that pregnant bitches and puppies needs to be dewormed during the last weeks of pregnancy and first few weeks of age after whelping (Roddie et al., 2008).

\section{Transmission of Toxoplasmosis}

Toxoplasmosis is the most common zoonotic parasite throughout the world, caused by Toxoplasma gondii (Dubey, 2010). It is a facultative heteroxenous, polyxenous protozoon parasite. Transmitted by several route in different host species. Infective stages of parasite are viz. tachyzoites, bradyzoites seen in tissue cysts and sporozoites containing sporulated oocysts in it. Oocysts released form definitive host are highly infective to several non-feline mammalian hosts which indicating adaptations of parasite for fecal-oral transmission in these species including humans (Dubey, 2009). All three stages are infectious to both intermediate as well as definitive hosts. They get infection by ingestions of infectious oocysts from environment, ingestion of tissue cysts in raw or undercooked meat or offal of intermediate hosts, or by transplacental transmission of tachyzoites (Dubey, 1993; Dubey et al., 1998). Transmission may also take place by tachyzoites from blood products, unpasteurized milk and tissue transplants. Consumption of uncooked pork and mutton has been considered as a major route of transmission to human beings in past (Tenter et al., 2000).

Transmission through Tissue Cysts of T. gondi Tissue cysts of $T$. gondii are considered as an important source of transmission to human beings. Tissue cysts are less resistant to environmental conditions whereas oocysts are relatively resistant to changes in temperature and maintain their infectivity even refrigerated at $4^{\circ} \mathrm{C}$ (Dubey et al., 1990). Tissue cysts may also survive at freezing temperatures $\left(-8^{\circ} \mathrm{C}\right)$ for more than a week (Kotula et al., 1991). But, majority of tissue cysts are killed by freezing at $-12^{\circ} \mathrm{C}$. Certain strains of T. gondii may resistant to freezing (Kuticic and Wikerhauser, 1996). In contrast, tissue cyst in meat is normally killed by heating to $67^{\circ} \mathrm{C}$ (Tenter et al., 2000).

\section{Toxoplasma Oocysts Survival and Transmission IN ENVIRONMENT}

Domestic feline and other feline species may be infected 
with T. gondii by ingestion of infectious oocysts or tissue cyst. Infected cats shed huge numbers of oocysts (up to 100 million oocysts) after an initial infection with $T$. gondii (Dubey, 1996; Omata et al., 1990). Under optimal conditions like adequate humidity, aeration and warm climate, oocysts sporulates and become potentially infectious in 6 days (Dubey, 1986). Further, secondary shedding of oocysts may be induced in cats that challenged with $T$. gondii after 6 years of initial infection (Dubey 1995a; Dubey, 1995b). Sporulated oocysts of T. gondii are resistant to ambient conditions. They survive cold and resist dehydration and may remain infectious up to 18 months in soil or sand (Frenkel, 2000). Sporulated oocysts are impervious and very resistant to common disinfectants (Kuticic et al., 1996). Immunocompromised persons and pregnant women (high risk group) should maintain good hygienic habits. They should clean vegetables and fruits properly before consuming, which may contaminate with cat faeces (Tenter et al., 2000).

\section{EMERGENCE OF GIARDIASIS}

Giardia duodenalis is the widespread intestinal parasite of humans and mammals all over the world. It is a familiar and regular cause for sickness of human beings at several occasions. Epidemiology revealed that humans are the reservoir host for human giardiasis due to person to person direct transmission. But canines and felines carry this $\mathrm{Gi}^{-}$ ardia which may be infective to humans, thus considered with zoonotic potential in immunocompromised individuals (Robertson et al., 2000). Disease transmission mainly occurs by feco-oral route by ingestion of infective stage cysts tainted with food and water (Hunter and Thompson, 2005; Kasprzak et al., 1989; Batchelor et al., 2008). Eight common genetic groups have been reported out of which, A and $\mathrm{B}$ genotypes are observed in both animals and humans (Monis et al., 2009; Thompson and Monis, 2011; Thompson et al., 2008). Traub et al. (2004a) reported the prevalence of infection in tea estate personnel (up to 39 and $16 \%$ assemblage of B and A respectively) especially in Assam state of India. Similar findings are observed by Thompson (2004) while working with Giardia from humans and dogs, suggested that dogs got infection from human reservoir. Further, these enteric protozoan parasites are impassive to anthelmintics, which are at present use. These intracellular coccidian parasite may colonize the place vacated by other intestinal parsites like D. caninum and T. canis (Robertson et al., 2000).

\section{OCCASIONAL ZOONOTIC RISK FROM CRYPTOSPORIDIUM}

Cryptosporidium spp., is the obligate intracellular coccidian parasite which mainly infect gastrointestinal tracts and respiratory of a several hosts, especially lambs, calves, kids and piglets. Cryptosporidium parvum and C. hominis are the common coccidian parasites of humans and C. canis (canines ) and C. felis (feline) are less frequent strains concerned with infection of humans (Scorza and Lappin, 2005). Feline and canine play a significant role in spread of cryptosporidiosis to humans. Molecular genetic studies revealed that $C$. parvum is not a sole identical species. It consists of six genetically distinct genotype, appear similar in morphology; out of which merely two genotype may be competent to infect immunocompetent humans like AIDS patients (Morgan et al., 1998a; Morgan et al., 1998b). It is necessary that veterinarians need to notify their clients on risk involved. Further contact with pet feline and canine feces needs to be avoided (Lucio-Forster et al., 2010).

\section{Transmission of Ancylostomiasis}

Common hookworms for canines are: Ancylostoma caninum, A. ceylanicum A. braziliense, and Uncinaria stenocephala; and for feline are: Ancylostoma tubaeforme, A. ceylanicum A. braziliense, and U. stenocephala. Persons coming in contact with sand which was contaminated by the faeces of canines and felines hookworms larvae may causes cutaneous larva migrans (CLM). CLM observed in humid areas with persons who crawl underneath buildings (Schantz, 1999). Ancylostomia spp. also causes eosinophilic pneumonitis, focal myositis, erythema multiforme, folliculitis and ophthalmological signs in humans (Prociv and Croese, 1996; Landmann and Prociv, 2003). Eggs passed in host's faeces hatches and hookworm larvae released will develop in to infective stage (filariform larva). It gains entry in to final host by skin penetration or ingestion. Infective somatic migration observed in canines where puppies infected by transmammary route, which is uncommom in felines (Bowman, 2010).

\section{EMERGENCE OF ANCYLOSTOMA CEYLANICUM}

Ancylostoma ceylanicum is widely distributed in canine and feline in Asian countries which remains an unexplored or less understood zoonotic disease. Current molecular based assays revealed that $A$. ceylanicum is a common hookworm infecting humans which comprised of $6-23 \%$ of total hookworm infection (Traub et al., 2008; Jiraanankul et al., 2011). Further, sero-prevalence in canines and feline were around 62\% in North-east part of India (Traub et al., 2007b). Natural cases of $A$. ceylanicum have been reported in human populations all over the world where hookworm infections are endemic in canines and felines, but exact clinical reports are lacking. As like any other anthroponotic hookworms, patent $A$. ceylanicum in adult humans lodges in jejunum. Larger numbers of worms causes anaemia, abdominal distension and discomfort, diarrhea and peripher- 
al eosinophilia (Anten and Zuidema, 1964; Hsu and Lin, 2012; Croese et al., 1994). Investigations which combine clinical, pathological data along with molecular diagnostic tool may shed the light for future to find its role as human pathogen. Further, it necessitates an incorporated and inter-sectorial "One Health" concept where large numbers of canines share an intimate companionship with humans (Traub, 2013).

\section{Transmission of LeISHMANIASIS}

Canines in urban areas are the major source of infection for Leismania infantum (Molina et al., 1994; Giunchetti et al., 2006). Zoonotic leishmaniasis is re-emerged and endemic in Europe which was initially considered as insignificant. Leishmaniasis due to $L$. infantum distributed in Mediterranean region, in which canines are the substantiate spreader of infection (Fisa et al., 1999; Sideris et al., 1999). In recent times, infection due to canines is in high magnitude than the expected (Martin-Sanchez et al. 1999; Orndorff et al. 2000). It has been estimated that more that $75 \%$ of dogs has seropositivity against $L$. infantum, which harbors as subclinical or in apparent infections. Sharma et al. (2003) reported that the prevalence in canines for Leishmania tropica in Rajastan was about 23 to $40 \%$. Carrying pet animals to endemic areas for short visit may spread the disease and causes introduction of infection in virgin lands (Robertson, 2000).

\section{Transmission of DiPYLIDIASIS}

Dipylidium caninum is a common cestode of canines (dogs, cats and wild canids). Humans inadvertently infected under rare circumstances. Fleas act as an intermediate host for D. caninum. Cooked rice like proglottids (gravid tapeworm segments) contains packs of eggs are ingested by larvae of fleas. Infective cysticercoids develop simultaneously when larvae mature to adult fleas and transmission of cestode to canine take place due to accidental consumption of flea (Molina et al., 2003). Signs of infection in canines include anal pruritus with mild gastrointestinal signs. Children in contact with pet dogs are more susceptible to infection due to their tendency for pica, and a prominent clinical signs of dipylidiasis in children are presence of gravid segment of cestodes in faeces -proglottids (Mani and Maguire, 2009).

\section{PARASITIC ZOONOSES CONTROL}

Control of zoonotic diseases requires education of human population for appropriate cooking method of food before consumption, boiling of drinking water, civilizing hygiene and sanitary measures, but it is huge task to complete (Macpherson, 2005). On the other side, standard and scheduled veterinary care of pet and companion animals against parasitic diseases may prevent zoonotic transmission (Mani and Maguire, 2009). Feeding of pets with un- cooked meat should be strictly avoided. It has been estimated that almost all dogs (99\%) harbors at least any one type of zoonotic parasite in GI tract. Further, about 98\% of dogs are out of reach of veterinary care for any health conditions, which remains neither dewormed, nor vaccinated against any diseases (Saminathan et al., 2015). It is very difficult to launch any chemotherapeutic approach to get rid of GI zoonotic parasites in canines in rural circumstances due to involvement of huge cost and subsequent dosing of same dogs may be nightmare. Implementation of stray dog control program and creating public awareness are required. Veterinary officers and physicians should take active role in educating the human community, creating awareness, responsible ownership and implementation of government health control programs. Government funds can be utilized for stray and semi-domesticated dogs control programs and vaccination. Alternate non-chemotherapeutic measures can be utilized for control of zoonotic geohelminth infection by improved education, sanitary measures; personal and environmental hygiene may also decrease and prevent the occurrence of parasitic zoonoses from dogs in rural India (Traub et al., 2007a).

\section{CONCLUSION AND FUTURE PERSPECTIVES}

Creating awareness among pet owners and animal handlers have key role in preventing the incidence and occurrence of infections of emerging and re-emerging zoonotic pet parasites. Pivotal knowledge of veterinarians, veterinary scientist, researches and physicians needs to be utilized to minimize the potential parasitic zoonoses by careful monitoring of signs of diseases in humans and animals. Veterinarians in the field are in right place to create awareness and issue sound recommendations, advice, suggestions and guidelines regarding prevention of parasitic infections by timely preventive medications. Widespread and extensive awareness programs are required to reduce the frequency of parasitic zoonotic infections so that pets can be integral family member in house all the way throughout the world. Deterrence and control of emerging and re-emerging parasitic zoonotic infections necessitate a universal pledge not only from scientific community but also from economists, politicians and health professionals to distribute apt financial support in order to carry out intensive control measures. Complete remedial supervision with forecasted plans needs to be created in alliance with scientific community especially with a team of researchers, physician and veterinarian may capitalize on promoting the health of both humans and pets.

\section{CONFLICT OF INTEREST}

There is no conflict of interest. 


\section{AUTHORS CONTRIBUTION}

M. Senthil Murugan, and B.R. Singh provided the main concept and designed the study. M. Senthil Murugan and D.K. Sinha managed acquisition of data while M. Senthil Murugan, S. Pavulraj, K. Arunvikram and A. Arun Prince Milton analysed and drafted the manuscript.

\section{REFERENCES}

-Akakpo AJ (1985). Le chien dans la socie'te 'Noire Africaine: un re'servoir de rage. In: Kuwert, E., Me'rieux, C., Koprowski, H., Bo" gel, K. (Eds.), Rabies in the Tropics. Springer, Berlin, pp. 516-517. http://dx.doi.org/10.1007/978-3-642-700606_66

-Almeida JC, Martins FD, Ferreira Neto JM, Santos MM, Garcia JL, Navarro IT, Kuroda EK, Freire RL (2015). Occurrence of Cryptosporidium spp. and Giardia spp. in a public water-treatment system, Paraná, Southern Brazil. Rev. Bras. Parasitol. Vet. pii: S1984-29612015005015051. http://dx.doi.org/10.1590/s1984-29612015051

-Anten JF, Zuidema PJ (1964). Hookworm infection in Dutch servicemen returning from West New Guinea. Trop. Geog. Med. 64(756): 216-224.

-Baker WS, Gray GC (2009). A review of published reports regarding zoonotic pathogen infection in veterinarians. J. Am. Vet. Med. Assoc. 234(10): 1271-1278. http://dx.doi. org/10.2460/javma.234.10.1271

-Batchelor DJ, Tzannes S, Graham PA (2008). Detection of endoparasites with zoonotic potential in dogs with gastrointestinal disease in the UK. Transbound. Emerg. Dis. 55(2): 99-104.

- Bhandarkar LD, Talvalkar GV (1973). Hydatid disease. A report of 35 cases. Indian J. Med. Sci. 27: 849-854

-Bhojraj SY, Shetty NR (1999). Primary hydatid disease of the spine: an unusual cause of progressive paraplegia. Case report and review of the literature. J. Neurosurg. 91(2): 216-218. http://dx.doi.org/10.3171/spi.1999.91.2.0216

-Bowman DD, Montgomery SP, Zajac AM, Eberhard ML, Kazacos KR (2010). Hookworms of dogs and cats as agents of cutaneous larva migrans. Trends. Parasitol. 26(4): 162 167.

- Chai JY, Murrell KD, Lymbery AJ (2005). Fish-borne parasitic zoonoses: Status and issues. Int. J. Parasitol. 35(11-12): 1233-1254. http://dx.doi.org/10.1016/j.ijpara.2005.07.013

- Chomel BB (1992). Zoonoses of House Pets Other Than Dogs, Cats and Birds. Pead. Inf. Dis. J. 11: 479-487. http://dx.doi. org/10.1097/00006454-199206000-00011

- Conraths FJ, Deplazes P (2015). Echinococcus multilocularis: Epidemiology, surveillance and state-of-the-art diagnostics from a veterinary public health perspective. Vet Parasitol. pii: S0304-4017(15)00367-2.

- Croese J, Loukas A, Opdebeeck J, Fairley S, Prociv P (1994). Human enteric infection with canine hookworms. Ann. Intern. Med. 120(5): 369-374. http://dx.doi. org/10.7326/0003-4819-120-5-199403010-00003

-Daniels TJ, Bekoff M (1989). Spatial and temporal resource use by feral and abandoned dogs. Ethology. 81(4): 300-312. http://dx.doi.org/10.1111/j.1439-0310.1989.tb00776.x

- Dar FK, Alkarmi T (1997). Cystic echinococcosis in the Gulf Littoral States. In: Andersen, F.L., Ouhelli, H., Kachani, M. (Eds.), Compendium on Cystic Echinococcosis in Africa and in Middle Eastern Countries with Special Reference to Morocco. Brighman Young University, Provo, UT, pp. 281-291.

-d'Ovidio D, Noviello E, Pepe P, Del Prete L, Cringoli G, Rinaldi L (2015). Survey of Hymenolepis spp. in pet rodents in Italy. Parasitol. Res. 2015 Aug 21.

-Dubey JP (1986). Toxoplasmosis in cats. Feline Pract. 16: 12-45

-Dubey JP (1993). Toxoplasma, Neospora, Sarcocystis, and other tissue cyst forming coccidia of humans and animals. In: Kreier JP, editor. Parasitic protozoa, $2^{\text {nd }}$ ed. Parasitic protozoa, vol. 6. 1993. pp. 1-158.

-Dubey JP (1996). Infectivity and pathogenicity of Toxoplasma gondii oocysts for cats. J. Parasitol. 82(6): 957-961.

-Dubey JP (2009). History of the discovery of the life cycle of Toxoplasma gondii. Int. J. Parasitol. 39(8): 877- 882. http:// dx.doi.org/10.1016/j.ijpara.2009.01.005

-Dubey JP (2010). Toxoplasmosis of Animals and Humans. Boca Raton, New York: CRC Press Inc. 1-313. Second.

-Dubey JP, Kotula AW, Sharar A, Andrews CD, Lindsay DS (1990). Effect of high temperature on infectivity of Toxoplasma gondii tissue cysts in pork. J. Parasitol. 76(2): 201-204.

- Dubey JP (1995a). Duration of immunity to shedding of Toxoplasma gondii oocysts by cats. J. Parasitol. 81(3): 410415. http://dx.doi.org/10.2307/3283823

-Dubey JP, Lappin MR, Thulliez P (1995b). Long-term antibody responses of cats fed Toxoplasma gondii tissue cysts.J.Parasitol. 81(6): 887-893. http://dx.doi.org/10.2307/3284035

-Dubey JP, Lindsay DS, Speer CA (1998). Structures of Toxoplasma gondii tachyzoites, bradyzoites, and sporozoites and biology and development of tissue cysts. Clin. Microbiol. Rev. 11(2): 267-299.

-Dutta JK (2002). Disastrous results of indigenous methods of rabies prevention in developing countries. Int. J. Infect. Dis. 6(3): 236-237. http://dx.doi.org/10.1016/S12019712(02)90118-9

-Eckert J, Conraths FJ, Tackmann K (2000). Echinococcosis: an emerging or re-emerging zoonosis? Int. J. Parasitol. 30(12-13): 1283-1294. http://dx.doi.org/10.1016/S00207519(00)00130-2

-Eckert J, Schantz PM, Gasser RB (2000b). Geographic distribution and prevalence of echinococcosis. In: Eckert J, Gemmell MA, Meslin F-X, Pawlowski Z, editors. WHO/ OIE manual on echinococcosis in humans and animals. Paris: Office International des EÂ pizooties, in press.

- Finsterer J, Auer H (2007). Neurotoxocarosis. Rev. Inst. Med. Trop. Sao Paulo. 49(5): 279 -287. http://dx.doi. org/10.1016/j.neuro.2006.12.009

-Fisa R, Gallego M, Castillejo S, Aisa MJ, Serra T, Riera C, Carrió J, Gállego J, Portús M (1999). Epidemiology of canine leishmaniasis in Catalonia (Spain) the example of the Priorat focus. Vet. Parasitol. 83(2): 87-97. http://dx.doi. org/10.1016/S0304-4017(99)00074-6

- Franco Sandoval LO, Caballero García Mde L, Hernández GR, Moreno García MA, Jiménez Cardoso E (2012). Molecular similarities and differences between Trichinella spp., isolated from canine skeletal muscle in Zacatecas, Mexico. Exp Parasitol. 131(2): 148-52. http://dx.doi.org/10.1016/j.exppara.2012.03.004

- Frank R, Kuhn T, Mehlhorn H, Rueckert S, Pham D, Klimpel S (2013). Parasites of wild rabbits (Oryctolagus cuniculus) from an urban area in Germany, in relation to worldwide results. Parasitol. Res. 112(12): 4255-66. http://dx.doi.org/10.1007/ 


\section{s00436-013-3617-7}

- Frenkel JK (1990). Transmission of toxoplasmosis and the role of immunity in limiting transmission and illness. J. Am. Vet. Med. Assoc. 196(2): 233-240.

-Frenkel JK (2000). Biology of Toxoplasma gondii. In: AmbroiseThomas P, Peterse E, editors. Congenital toxoplasmosis: scientific background, clinical management and control.Paris: Springer-Verlag, pp. 9-25. http://dx.doi.org/10.1007/9782-8178-0847-5_2

- Geffray L (1999). Infections associated with pets. Rev. Med. Int. 20(10): 888-901. http://dx.doi.org/10.1016/S02488663(00)80094-6

- Giunchetti RC, Mayrink W, Genaro O, Carneiro CM, CorreaOliveira R, Martins-Filho OA, Marques MJ, Tafuri WL, Reis AB (2006). Relationship between canine visceral leishmaniosis and the Leishmania (Leishmania) chagasi burden in dermal inflammatory foci. J. Comp. Pathol. 135(23): 100-107. http://dx.doi.org/10.1016/j.jcpa.2006.06.005

-Headey B, Krause P (1999). Health benefits and potential budget savings due to pets. Australian and German survey results. Aust. Social Mon. 2(2): 4-6.

-Hendrix CM, Blagburn BL (1988). Reptilian pentastomiasis: a possible emerging zoonosis. Compendium Small Anim. 10(1): 46-51

-Holland CV, O'connor P, Taylor M, Hughes G, Girdwood R, Smith H (1991). Families, parks, gardens and toxocariasis. Scand. J. Infect. Dis. 23(2): 225-231. http://dx.doi. org/10.3109/00365549109023405

-Hsu YC, Lin JT (2012). Images in clinical medicine. Intestinal infestation with Ancylostoma ceylanicum. N. Engl. J. Med. 366(13): e20. http://dx.doi.org/10.1056/NEJMicm1101717

-Hunter PR, Thompson RCA (2005). The zoonotic transmission of Giardia and Cryptosporidium. Int. J. Parasitol.35(11-12): 1181-1190. http://dx.doi.org/10.1016/j.ijpara.2005.07.009

-Jacobs D, Woodruff A, Prole J (1977). Toxocara infection and kennel workers. Br. Med. J. 1(6052): 51. http://dx.doi. org/10.1136/bmj.1.6052.51

-Jennings LB (1997). Potential benefits of pet ownership in health promotion. J. Holist. Nurs. 15(4): 358-372.

- Jiraanankul V, Aphijirawat W, Mungthin M, Khositnithikul R, Rangsin R, Traub RJ, Piyaraj P, Naaglor T, Taamasri P, Leelayoova $S$ (2011). Incidence and risk factors of hookworm infection in a rural community of central Thailand. Am. J. Trop. Med. Hyg. 84(4): 594-598. http://dx.doi.org/10.4269/ ajtmh.2011.10-0189

-Johnson ST, Cable RG, Tonnetti L, Spencer B, Rios J, Leiby DA (2009). Seroprevalence of Babesia microti in blood donors from Babesia endemic areas of the north-eastern United States: 2000 through 2007. Transfusion. 49(12): 2574-2582. http://dx.doi.org/10.1111/j.1537-2995.2009.02430.x

-Juckett G (1997). Pets and parasites. Am. Fam. Physician. 56: 1763-1778.

-Kahn LH (2006). Confronting zoonoses, linking human and veterinary medicine. Emerg. Infect. Dis. 12(4): 556-561. http://dx.doi.org/10.3201/eid1204.050956

-Kapel CM, Torgerson PR, Thompson RC, Deplazes P (2006). Reproductive potential of Echinococcus multilocularis in experimentally infected foxes, dogs, raccoon dogs and cats. Int. J. Parasitol. 36(1): 79 - 86. http://dx.doi.org/10.1016/j. ijpara.2005.08.012

-Kasprzak W, Pawlowski Z (1989). Zoonotic aspects of giardiasis: a review. Vet. Parasitol. 32(2-3): 101-108. http://dx.doi. org/10.1016/0304-4017(89)90110-6
-Khan MB, Riaz M, Bari ME (2015). Multiple cerebral hydatid cysts in 8-year-old boy: A case report and literature review of a rare presentation. Surg Neurol Int. 6:125. http://dx.doi. org/10.4103/2152-7806.161785

-Kjos SA, Snowden KF, Craig TM, Lewis B, Ronald N, Olson JK (2008). Distribution and characterization of canine Chagas disease in Texas. Vet. Parasitol. 152(3-4): 249-256. http:// dx.doi.org/10.1016/j.vetpar.2007.12.021

-Kotula AW, Dubey JP, Sharar AK, Andrews CD, Shen SK, Lindsay DS (1991). Effect of freezing on infectivity of Toxoplasma gondii tissue cysts in pork. J. Food Prot. 54(9): 687-690.

-Kuticic V, Wikerhauser T (1996). Studies of the effect of various treatments on the viability of Toxoplasma gondii tissue cysts and oocysts. In: Gross U, editor. Toxoplasma gondii. Berlin: Springer-Verlag, pp. 261-265. http://dx.doi. org/10.1007/978-3-642-51014-4_23

-Landmann JK, Prociv P (2003). Experimental human infection with the dog hookworm, Ancylostoma caninum. Med. J. Aust. 178(2): 69-71.

-Lee AC, Schantz PM, Kazacos KR, Montgomery SP, Bowman DD (2010). Epidemiologic and zoonotic aspects of ascarid infections in dogs and cats. Trend. Parasitol. 26(4): 155-161. http://dx.doi.org/10.1016/j.pt.2010.01.002

-Liu Q, Wei F, Liu W, Yang S, Zhang X (2008). Paragonimiasis: an important food-borne zoonosis in China. Trend. Parasitol. 24(7): 318-323. http://dx.doi.org/10.1016/j.pt.2008.03.014

-Lucio-Forster A, Griffiths JK, Cama VA, Xiao L, Bowman DD (2010). Minimal zoonotic risk of cryptosporidiosis from pet dogs and cats. Trend. Parasitol. 26(4): 174 -179. http:// dx.doi.org/10.1016/j.pt.2010.01.004

-Lun ZR, Gasser RB, Lai DH, Li AX, Zhu XQ, Yu XB, Fang YY (2005). Clonorchiasis: a key foodborne zoonosis in China. Lancet. Infect. Dis. 5(1): 31-41. http://dx.doi.org/10.1016/ S1473-3099(04)01252-6

-Macpherson CN (2005).Human behaviour and the epidemiology of parasitic zoonoses. Int. J. Parasitol. 35(11-12): 1319-1331. http://dx.doi.org/10.1016/j.ijpara.2005.06.004

-Macpherson CN, Bartholomot B, Frider B (2003). Application of ultrasound in diagnosis, treatment, epidemiology, public health and control of Echinococcus granulosus and E. multilocularis. Parasitology. 127: S21-S35. http://dx.doi. org/10.1017/S0031182003003676

-Macpherson CN, French CM, Stevenson P, Karstad L, Arundel JH (1985). Hydatid disease in the Turkana District of Kenya IV. The prevalence of Echinococcus granulosus infections in dogs and observations on the role of the dog in the lifestyle of the Turkana. Ann. Trop. Med. Parasitol. 79(1): 51-61.

-Malla, N, Aggarwal AK, Mahajan RC (2002). A serological study of human toxocariasis in north India. Natl. Med. J. India. 15(3): 145-147.

-Mani I, Maguire JH (2009). Small Animal Zoonoses and Immuncompromised Pet Owners. Top. Companion Anim. Med. 24(4): 164 -174. http://dx.doi.org/10.1053/j. tcam.2009.07.002

-Martin-Sanchez J, Lepe JA, Toledo A, Ubeda JM, Guevara DC, Morillas-Márquez F, Gramiccia M (1999). Leishmania (Leishmania) infantum enzymatic variants causing canine leishmaniasis in the Huelva province (south-west Spain). Trans. R. Soc. Trop. Med. Hyg. 93(5): 495-496. http:// dx.doi.org/10.1016/S0035-9203(99)90347-4

-McManus DP, Thompson RC (2003). Molecular epidemiology of cystic echinococcosis. Parasitology. 127: S37-51. http:// 
dx.doi.org/10.1017/S0031182003003524

- Milton AAP,Priya GB, Aravind M,Parthasarathy S, Saminathan M, Jeeva K, Agarwal RK (2015). Nosocomial infections and their surveillance in veterinary hospitals. Adv. Anim. Vet. Sci. 3(2s): 1-24. http://dx.doi.org/10.14737/journal. aavs/2015/3.2s.1.24

- Mirdha BR, Khokar SK (2002). Ocular toxocariasis in a North Indian population. J. Trop. Pediatr. 48(6): 328-330. http:// dx.doi.org/10.1093/tropej/48.6.328

-Molina R,Amela C, NietoJ, San-Andres M, Gonzalez F, Castillo JA, Lucientes J, Alvar J (1994). Infectivity of dogs naturally infected with Leishmania infantum to colonized Phlebotomus perniciosus. Trans. R. Soc. Trop. Med. Hyg. 88(4): 491-493. http://dx.doi.org/10.1016/0035-9203(94)90446-4

- Molina CP, Ogburn J, Adegboyega P (2003). Infection by Dipylidium caninum in an infant. Arch. Pathol. Lab. Med. 127(3): e157-e159.

-Monis PT, Cacciò SM, Thompson RC (2009). Variation in Giardia: towards a taxonomic revision of the genus. Trend. Parasitol. 25(2): 93-100. http://dx.doi.org/10.1016/j. pt.2008.11.006

- Morgan UM, Pallant L, Dwyer BW, Forbes DA, Rich G, Thompson RCA (1998a). Comparison of PCR and microscopy for detection of Cryptosporidium in human fecal samples: Clinical trial. J. Clin. Microbiol. 36(4): 995998.

- Morgan UM, Sargent KD, Deplazes P, Forbes DA, Spano F, Hertzberg H, Elliot A, Thompson RC (1998b). Molecular characterisation of Cryptosporidium from various hosts. Parasitology. 117(Pt 1): 31-37. http://dx.doi.org/10.1017/ S0031182098002765

-Moro P, Schantz PM (2009). Echinococcosis: a review. Int. J. Infect. Dis. 13(2): 125-133. http://dx.doi.org/10.1016/j. ijid.2008.03.037

-Moro PL, Cavero CA, Tambini M, Bricen oY, Jime'nez R, Cabrera L (2008). Identification of risk factors for cystic echinococcosis in a periurban population of Peru. Trans. R. Soc. Trop. Med. Hyg. 102(1): 75-78. http://dx.doi. org/10.1016/j.trstmh.2007.09.010

-Moro PL, Schantz PM (2006). Echinococcosis: historical landmarks and progress in research and control. Ann. Trop. Med. Parasitol. 100(8): 703-714. http://dx.doi. org/10.1179/136485906X112257

- Nowotny N, Deutz A (2000). Preventing zoonotic diseases in immunocompromised persons: the role of physicians and veterinarians [letter to the editor]. Emerg. Infect. Dis. 6(1) 208-209. http://dx.doi.org/10.3201/eid0602.000219

- O'lorcain P (1994a). Prevalence of Toxocara canis ova in public playgrounds in the Dublin area of Ireland. J. Helminthol. 68(3): 237-241. http://dx.doi.org/10.1017/ S0022149X00014401

- Omata Y, Oikawa H, Kanda M, Mikazuki K, Nakabayashi T, Suzuki N (1990). Experimental feline toxoplasmosis: humoral immune responses of cats inoculated orally with Toxoplasma gondii cysts and oocysts. Jpn. J. Vet. Sci. 52(4): 865-867. http://dx.doi.org/10.1292/jvms1939.52.865

- Orndorff GR, Cooper BA, Smith W, Ryan JR (2000). Canine visceral leishmaniasis in Sicily. Mil. Med. 165(1): 29-32.

-Paul M, King L, Carlin PE (2010). Zoonoses of people and their pets: a US perspective on significant pet-associated parasitic diseases. Trend. Parasitol. 26(4): 153-154. http:// dx.doi.org/10.1016/j.pt.2010.01.008

- Pawlowski ZS (1997). Critical points in the clinical management of cystic echinococcosis: a revised review. In: Andersen FL, Ouhelli H, Kachani M, editors. Compendium on cystic echinococcosis in Africa and in Middle Eastern Countries with special reference to Morocco. Provo, UT: Brigham Young University. pp. 119-135.

-Plant M, Zimmerman EM, Goldstein RA (1996). Health hazards to humans associated with domestic pets. Annu. Rev. Public Health. 17: 221-245. http://dx.doi.org/10.1146/ annurev.pu.17.050196.001253

-Prociv P, Croese J (1996). Human enteric infection with Ancylostoma caninum: hookworms reappraised in the light of a "new" zoonosis. Acta Trop. 62(1): 23-44. http://dx.doi. org/10.1016/S0001-706X(96)00016-2

-Qian MB, Utzinger J, Keiser J, Zhou XN (2015). Clonorchiasis. Lancet. pii: S0140-6736(15)60313-0.

-Rivero MR, Motta CE, Salas MM, Chiaretta A, Salomón OD (2015). Diphyllobothrium sp. in Canis familiaris from the subtropical area of Argentina (Puerto Iguazú, Misiones). Rev Argent Microbiol. pii: S0325-7541(15)00073-5.

-Robertson ID, Irwin PJ, Lymbery AJ, Thompson RC (2000). The role of companion animals in the emergence of parasitic zoonoses. Int. J. Parasitol. 30(12-13): 1369-1377. http:// dx.doi.org/10.1016/S0020-7519(00)00134-X

-Roddie G,Stafford P,Holland C,Wolfe A (2008).Contamination of $\mathrm{dog}$ hair with eggs of Toxocara canis. Vet. Parasitol.152(12): 85-93. http://dx.doi.org/10.1016/j.vetpar.2007.12.008

-Romig T, Ebi D, Wassermann M (2015). Taxonomy and molecular epidemiology of Echinococcus granulosus sensu lato. Vet Parasitol. pii: S0304-4017(15)00375-1.

-Rubinsky-Elefant G, Hirata CE, Yamamoto JH, Ferreira MU (2010). Human toxocariasis: Diagnosis, worldwide seroprevalences and clinical expression of the systemic and ocular forms. Ann. Trop. Med. Parasitol. 104(1): 3-23. http://dx.doi.org/10.1179/136485910x12607012373957

-Saminathan M, Gopalakrishnan A, Latchumikanthan A, Milton AAP, Aravind M, Dhama K, Singh R (2015). Histopathological and parasitological study of bloodsucking Haemonchus contortus infection in sheep. Adv. Anim. Vet. Sci. 3(2): 99-108. http://dx.doi.org/10.14737/ journal.aavs/2015/3.2.99.108

-Schantz P (1991). Parasitic zoonoses in perspective. Int. J. Parasitol. 21(2): 161-170. http://dx.doi.org/10.1016/00207519(91)90006-S

-Schantz PM (1994). Of worms, dogs and human hosts: Continuing challenges for veterinarians in prevention of human disease. J. Am. Vet. Med. Assoc. 204(7): 1023-1028.

-Schantz PM (1999). Sharing the burdens: Parasites of dogs and cats that infect human beings. In: Bredahuer M, editor. Pets, people and parasites, Publication 1/99 Continuing Veterinary Education. Murdoch: Murdoch University. Pp. 33-44.

-Scorza AV, Lappin MR (2005). Detection of Cryptosporidium spp. in feces of cats and dogs in the United States by PCR assay and IFA. J. Vet. Int. Med. 19: 437.

-Sharma V, Purohit SK, Sharma G, Joshi R, Mehta RD, Kochar DK (2003). Cutaneous leishmaniasis in dogs and human beings in Bikaner, Rajasthan. J. Vet. Public Health. 1(1): 69 $-73$.

-Sideris V, Papadopoulou G, Dotsika E, Karagouni E (1999). Asymptomatic canine leishmaniasis in Greater Athens area, Greece. Eur. J. Epidemol. 15(3): 271-276. http://dx.doi. org/10.1023/A:1007526401175

-Simón F, Siles-Lucas M, Morchón R, González-Miguel J, 
Mellado I, Carretón E, Montoya-Alonso JA (2012). Human and animal dirofilariasis: The emergence of a zoonotic mosaic. Clin. Microbiol. Rev. 25(3): 507-544. http://dx.doi. org/10.1017/S1751731112001024

-Singh SK, Dimri U, Ahmed QS, Sayedda K, Singh KV (2013). Efficacy of doramectin in Trixacarus caviae infestation in guinea pigs (Cavia porcellus). J. Parasit. Dis. 37(1): 148-50.

-Smith H, Holland C, Taylor M, Magnaval JF, Schantz P, Maizels $\mathrm{R}$ (2009). How common is human toxocariasis? Towards standardizing our knowledge. Trend. Parasitol. 25(4): 182188. http://dx.doi.org/10.1016/j.pt.2009.01.006

-Sterneberg-van der Maaten T, Turner D, Van Tilburg J, Vaarten J (2015). Benefits and risks for people and livestock of keeping companion animals: searching for a healthy balance. J. Comp. Pathol. pii: S0021-9975(15)00107-3.

-Tappe D, Haeupler A, Schäfer H, Racz P, Cramer JP, Poppert $S$ (2013). Armillifer armillatus pentastomiasis in African immigrant, Germany. Emerg. Infect. Dis. 19(3): 507-508. http://dx.doi.org/10.3201/eid1903.121508

- Tenter AM, Heckeroth AR, Weiss LM (2000). Toxoplasma gondii: from animals to humans. Int. J. Parasitol. 30(1213): 1217-1258. http://dx.doi.org/10.1016/S00207519(00)00124-7

-Thompson J, Yang R, Power M, Hufschmid J, Beveridge I, Reid S, Ng J, Armson A, Ryan U (2008). Identification of zoonotic Giardia genotypes in marsupials in Australia. Exp. Parasitol. 120(1): 88-93. http://dx.doi.org/10.1016/j. exppara.2008.05.002

-Thompson RC (1995). Biology and systematics of Echinococcus. In: Thompson RC, Lymbery AJ, editors. Echinococcus and hydatid disease. London: CAB International. Pp. 1-7.

-Thompson RC, McManus DP (2002). Towards a taxonomic revision of the genus Echinococcus. Trend. Parasitol. 18(10): 452-457. http://dx.doi.org/10.1016/S14714922(02)02358-9

-Thompson RC, Monis PT (2004). Variation in Giardia: implications for taxonomy and epidemiology. Adv. Parasitol. 58: 69-137. http://dx.doi.org/10.1016/S0065308X(04)58002-8

-Thompson RCA (1999). Veterinary parasitology: looking to the next millennium. Parasitol. Today. 15(8): 320-325. http:// dx.doi.org/10.1017/S0031182099004151

-Thompson RCA, Deplazes P, Eckert J (2003). Observations on the development of Echinococcus multilocularis in cats. J. Parasitol. 89(5): 1086-1088. http://dx.doi.org/10.1645/GE3150RN

-Traub RJ (2013). Ancylostoma ceylanicum, a re-emerging but neglected parasitic zoonosis. Int. J. Parasitol. 43(12-13): 1009-1015. http://dx.doi.org/10.1016/j.ijpara.2013.07.006

- Traub RJ, Hobbs RP, Adams PJ, Behnke JM, Harris PD, Thompson RC (2007b). A case of mistaken identityreappraisal of the species of canid and felid hookworms (Ancylostoma) present in Australia and India. Parasitology. 134(Pt 1): 113-119. http://dx.doi.org/10.1017/ S0031182006001211

-Traub RJ, Inpankaew T, Sutthikornchai C, Sukthana Y, Thompson RC (2008). PCR-based coprodiagnostic tools reveal dogs as reservoirs of zoonotic ancylostomiasis caused by Ancylostoma ceylanicum in temple communities in Bangkok. Vet. Parasitol. 155(1-2): 67-73. http://dx.doi. org/10.1016/j.vetpar.2008.05.001

- Traub RJ, Monis PT, Robertson I, Irwin P, Mencke N, Thompson RC (2004b). Epidemiological and molecular evidence supports the zoonotic transmission of Giardia among humans and dogs living in the same community. Parasitology.128(Pt 3): 253-262.http://dx.doi.org/10.1017/ S0031182003004505

- Traub RJ, Robertson ID, Irwin P, Mencke N, Andrew Thompson RC (2004a). The prevalence, intensities and risk factors associated with geohelminth infection in teagrowing communities of Assam, India. Trop. Med. Int. Health. 9(6): 688-701. http://dx.doi.org/10.1111/j.13653156.2004.01252.x

-Traub RJ, Robertson ID, Irwin P, Mencke N, Thompson RC (2002). The role of dogs in transmission of gastrointestinal parasites in a remote tea-growing community in northeastern India. Am. J. Trop. Med. Hyg. 67(5): 539-545.

-Traub, RJ, Robertson ID, Irwin PJ, Mencke N, Thompson RC (2005). Canine gastrointestinal parasitic zoonoses in India. Trend. Parasitol. 21(1): 42-48. http://dx.doi.org/10.1016/j. pt.2004.10.011

-Watson-Jones DL, Macpherson CNL (1988). Hydatid disease in the Turkana District of Kenya VI, Man: Dog contact and its role in the transmission and control of hydatidosis amongst the Turkana. Ann. Trop. Med. Parasitol. 82(4): 343-356.

-Wolfe A, Wright IP (2003). Human toxocariasis and direct contact with dogs. Vet. Rec. 152(14): 419-422. http://dx.doi. org/10.1136/vr.152.14.419

-Wolfe A, Wright IP (2004). Parasitic nematode eggs in fur samples from dogs. Vet. Rec. 154(13): 408-409. http:// dx.doi.org/10.1136/vr.154.13.408

-World Health Organization (1996). Report of the 3rd International Symposium on Rabies in Asia. WHO/EMC/ ZOO.96.8

-World Health Organization (2003). The World Health Report. WHO (www.who.int/evidence/bod)

-Xu LQ, Chen YD, Sun FH, Cai L, Fang RY, Wang LP, Liu X, Feng Y, Li H (2005). A national survey on current status of the important parasitic diseases in human population. Chin. J. Parasitol. Parasit. Dis. 23(5): 332-340.

-Yang YR, Sun T, Li Z, Zhang J, Teng J, Liu X, Liu R, Zhao R, Jones MK, Wang Y, Wen H, Feng X, Zhao Q, Zhao Y, Shi D, Bartholomot B, Vuitton DA, Pleydell D, Giraudoux P, Ito A, Danson MF, Boufana B, Craig PS, Williams GM, McManus DP (2006). Community surveys and risk factor analysis of human alveolar and cystic echinococcosis in Ningxia Hui Autonomous Region, China. Bull. World Health Organ. 84(9): 714-721. http://dx.doi.org/10.2471/ BLT.05.025718

-Zanzani SA, Di Cerbo AR, Gazzonis AL, Genchi M, Rinaldi L, Musella V, Cringoli G, Manfredi MT (2014). Canine fecal contamination in a metropolitan area (Milan, northwestern Italy): prevalence of intestinal parasites and evaluation of health risks. Scientific World Journal. 2014; 2014:132361.

-Zasloff RL, Kidd AH (1994). Loneliness and pet ownership among single women. Psychol. Rep. 75(2): 747-752. http:// dx.doi.org/10.2466/pr0.1994.74.3.747

-Zhou P, Chen N, Zhang RL, Lin RQ, Zhu XQ (2008). Food-borne parasitic zoonoses in China: perspective for control. Trend. Parasitol. 24(4): 190-196. http://dx.doi. org/10.1016/j.pt.2008.01.001 